\title{
Increased concentrations of nitrite in synovial fluid and serum samples suggest increased nitric oxide synthesis in rheumatic diseases
}

\author{
Adrian J Farrell, David R Blake, Richard M J Palmer, Salvador Moncada
}

\begin{abstract}
Cytokines induce nitric oxide synthesis by endothelial cells, macrophages and polymorphonuclear leucocytes, indicating a role for nitric oxide in inflammatory processes. Nitric oxide production was therefore measured indirectly as nitrite in serum and synovial fluid samples from patients with rheumatoid arthritis (RA) and osteoarthritis (OA) together with serum samples from healthy volunteers matched for age and sex. Serum nitrite concentrations in patients with RA and OA were significantly higher than in controls. In both disease groups synovial fluid nitrite was significantly higher than serum nitrite, implying nitric oxide synthesis by the synovium. Serum and synovial fluid nitrite concentrations in RA were also significantly higher than those in OA. These data show increased nitric oxide production in RA and $O A$ and suggest a role for nitric oxide as an inflammatory mediator in rheumatic diseases.
\end{abstract}

(Ann Rheum Dis 1992; 51: 1219-1222)

Nitric oxide has been shown to be the endothelium derived relaxing factor. ${ }^{1}$ It is synthesised by the vascular endothelium from L-arginine and interacts with the haem group of guanylate cyclase to increase cGMP formation in vascular smooth muscle cells. Altered nitric oxide synthesis may affect the pathogenesis of some cardiovascular diseases. ${ }^{2}$ The $\mathrm{L}$-arginine to nitric oxide biosynthetic pathway has also been identified in numerous other cells and tissues including the adrenal glands, ${ }^{3}$ brain, ${ }^{4}{ }^{5}$ platelets, ${ }^{6}$ and some non-adrenergic non-cholinergic nerve terminals, ${ }^{7}$ suggesting a more widespread role for nitric oxide in the regulation of cellular function and communication. ${ }^{2}$ In all these cells nitric oxide is synthesised by a constitutive $\mathrm{Ca}^{2+}$ calmodulin dependent nitric oxide synthase. ${ }^{8}$ Nitric oxide is also generated by macrophages, ${ }^{9}$ polymorphonuclear leucocytes, ${ }^{10}$ lymphocytes, ${ }^{11}$ and hepatocytes, ${ }^{12}$ though in these cells an inducible enzyme is responsible for its synthesis. This enzyme is not $\mathrm{Ca}^{2+}$ dependent, is induced by cytokines, ${ }^{813} 14$ and its induction is inhibited by glucocorticoids. ${ }^{8}$ Moreover, its expression results in the sustained release of nitric oxide in amounts far in excess of those by the constitutive pathway. This enzyme was originally described in macrophages in which nitric oxide is essential for cytotoxicity against tumour cells and protozoa. ${ }^{914}$ The latter may require an interaction of nitric oxide with the superoxide anion, ${ }^{15}$ which although neutralising the effects of nitric oxide and superoxide may, via peroxynitrite, lead to the formation of hydroxyl radicals. ${ }^{16} 17$ This suggests a role for nitric oxide in inflammatory diseases and especially rheumatoid arthritis (RA), in which there is clear evidence for the release of cytokines $^{18}$ and for hypoxic reperfusion phenomena and free radical generation. ${ }^{19}$ For these reasons we have measured the concentrations of nitrite, a breakdown product of nitric oxide, in serum and synovial fluid from patients with RA and osteoarthritis (OA) and in the serum of controls matched for age and sex.

\section{Patients and methods}

Paired serum and synovial fluid samples were obtained from 25 patients with active RA fulfilling the 1987 American Rheumatism Association criteria (19 women, six men, mean age 62.4 years) and 19 patients with primary $O A$ (10 women, nine men, mean age $62 \cdot 8$ years). ${ }^{20}$ Diagnostic accuracy was assured by clinical review and concurrent laboratory assessment in all patients, which included determination of serum rheumatoid factor, serum $C$ reactive protein (CRP), synovial fluid white blood cell counts, and, in appropriate cases, microscopic study of synovial fluid samples for crystals. All patients were receiving either therapeutic or diagnostic knee aspiration. Serum samples were also obtained from 16 healthy volunteers matched for age and sex. After centrifugation at $2500 \mathrm{~g}$ serum and cell free synovial fluid were stored at $-70^{\circ} \mathrm{C}$ until analysis.

Investigating the role of nitric oxide in RA or any other disease requires a simple measure of nitric oxide. Its short half life makes its direct measurement impractical, though in aqueous solutions nitric oxide decays to yield equal amounts of nitrite and nitrate, ${ }^{1}$ which are used as indices of nitric oxide synthesis in vitro. In vivo dietary intake might obscure any differences between samples or disease groups, however. In this respect British surveys have estimated a mean daily intake from food of 95 $\mathrm{mg}$ nitrate and $1.4 \mathrm{mg}$ nitrite, ${ }^{21}$ equivalent to plasma nitrate concentrations of $30 \mu \mathrm{mol} / \mathrm{l}^{22}$ and undetectable concentrations of nitrite. ${ }^{23}$ Lower dietary nitrite intake and our preliminary findings of nitrite concentrations less than $1 \mu \mathrm{mol} / \mathrm{l}$ suggested that nitrite offers a more sensitive index of endogenous nitric oxide production and is less subject to dietary influences than nitrate.

The nitrite content of the samples was determined by chemiluminescence. ' Nitrite was reduced to nitric oxide by refluxing samples in $1.5 \%$ sodium iodide in glacial acetic acid and 
was carried to the reaction chamber by a nitrogen stream bubbled through the reflux mixture. Nitric oxide is determined by the chemiluminescence of its reaction with ozone. The absolute concentration of nitrite in human samples was determined by reference to a standard solution of sodium nitrite. This method is extremely sensitive and can measure picomolar amounts of nitric oxide. A considerable advantage was that biological samples were analysed without further preparatory steps. This avoids techniques such as deproteination with organic acids which, in our experience, completely remove nitrite by converting it to gaseous nitric oxide.

Nitrite concentrations in synovial fluid and serum samples from patients with rheumatoid arthritis $(R A)$, osteoarthritis $(O A)$, and serum samples from controls matched for age and sex

\begin{tabular}{|c|c|c|c|}
\hline & $\begin{array}{l}\text { Mean (SEM) } \\
\text { concentration of } \\
\text { nitrite in symovial } \\
\text { fluid ( } \mu \text { molll) }\end{array}$ & $\begin{array}{l}\text { Mean (SEM) } \\
\text { concentration of } \\
\text { nitrite in serum } \\
(\mu \mathrm{mol} / \mathrm{l})\end{array}$ & $p$ Value ${ }^{*}$ \\
\hline $\begin{array}{l}\text { Patients with RA }(n=25) \\
\text { RA matched controls }(n=16) \\
\text { Patients with OA }(n=19) \\
\text { OA matched controls }(n=11)\end{array}$ & $\begin{array}{l}0.910(0.162) \\
0.354(0.029)\end{array}$ & $\begin{array}{l}0.440(0.052) \\
0.147(0.016) \\
0.213(0.049) \\
0.142(0.018)\end{array}$ & $\begin{array}{l}<0.01 \\
<0.001 \\
<0.05 \\
<0.05\end{array}$ \\
\hline
\end{tabular}

${ }^{*} \mathrm{RA}$ synovial fluid $v$ OA synovial fluid, $\mathrm{p}<0.01$; RA serum $v$ OA serum, $\mathrm{p}<0.005$.

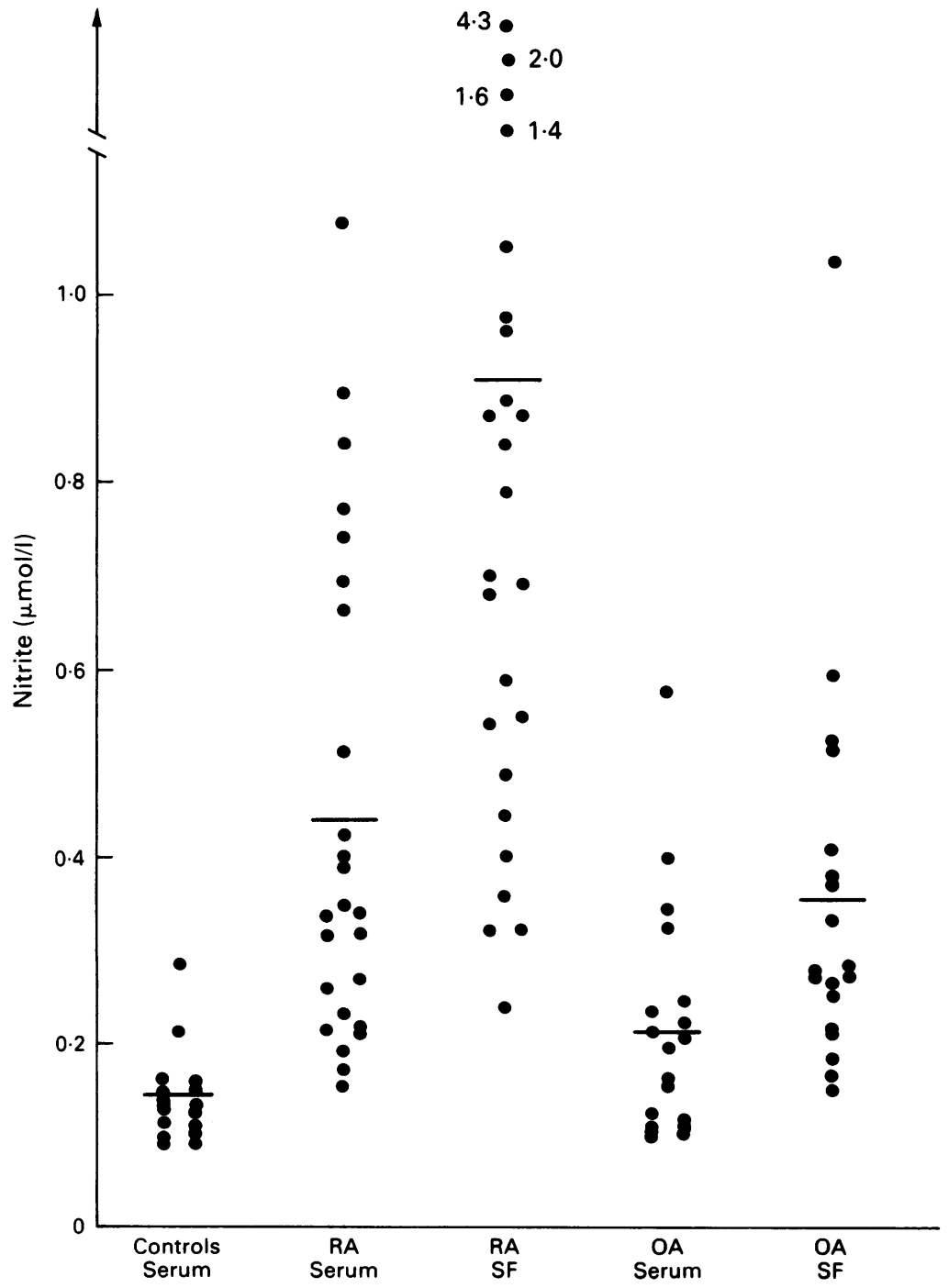

Nitrite concentrations in synovial fluid $(S F)$ and serum samples from patients with rheumatoid arthritis $(R A)$, osteoarthritis $(O A)$ and in serum samples from controls matched for age and sex.
There was no significant loss of nitrite from samples following freeze/thawing or storage at $-70^{\circ} \mathrm{C}$ for up to six months. After $15-18$ months storage at $-70^{\circ} \mathrm{C}$ the mean nitrite loss from samples was $11 \%$.

\section{Statistics}

The results in the patient and control groups were normally distributed and were analysed by Student's $t$ test. Correlation data were analysed using Kendall's rank correlation method. The study was performed with local ethical committee approval and in accordance with the articles of the Helsinki declaration.

\section{Results}

Mean nitrite concentrations in synovial fluid and serum samples were in the $\mu \mathrm{mol} / 1$ range (see table). The nitrite concentration in serum samples from patients with RA was over twice that of serum samples from patients with $O A$ $(p<0.005)$. It was also three times that of controls matched for age and sex (0.44 and $0.147 \mu \mathrm{mol} / 1$ respectively, $\mathrm{p}<0.001$ ) (figure). The serum nitrite concentration in patients with OA was also higher than that in controls matched for age and sex $(0.213$ and $0.142 \mu \mathrm{mol} / \mathrm{l}$ respectively; $\mathrm{p}<0.05$ ).

The mean nitrite concentration in synovial fluid in patients with RA was $0.91 \mu \mathrm{mol} / \mathrm{l}$, which was over twice the $0.44 \mu \mathrm{mol} / 1$ in serum samples $(p<0.01)$. The highest nitrite concentration recorded was $4.27 \mu \mathrm{mol} / \mathrm{l}$ in the synovial fluid of a patient with active RA (CRP $124 \mathrm{mg} / 1$, normal $<10 \mathrm{mg} / \mathrm{l}$ ) and was eight times that of the paired serum sample. The nitrite content of synovial fluid from patients with OA $(0.354$ $\mu \mathrm{mol} / \mathrm{l})$ was less than that of synovial fluid from patients with RA ( $p<0.01)$, but still higher than serum nitrite in patients with $O A$, which was $0.213 \mu \mathrm{mol} / 1(p<0.05)$. Synovial fluid nitrite was higher than the paired serum sample in $22 / 25$ patients with $R A$ and $16 / 19$ patients with OA.

Synovial fluid nitrite and serum nitrite concentrations were significantly correlated in patients with RA $(\tau=+0.315 ; \mathrm{p}<0.05)$. In patients with RA there was no significant correlation for serum nitrite $v \mathrm{CRP}$, synovial fluid nitrite $v \mathrm{CRP}$, the ratio synovial fluid/serum nitrite $v$ CRP, nor synovial fluid nitrite $v$ synovial fluid white blood cell count.

\section{Discussion}

This study clearly shows that in RA and OA nitrite concentrations are higher in synovial fluid than in serum samples, and by inference nitric oxide is produced by the synovium. This is consistent with the presence within inflamed synovium of nitric oxide generating cells such as endothelial cells, polymorphonuclear leucocytes, and macrophages. In OA higher nitrite concentrations in synovial fluid compared with serum samples could reflect the fact that patients with OA with large synovial effusions may belong to a subset of patients with prominent synovial inflammation. These findings indicate that the 
inducible nitric oxide pathway plays a part in inflammatory disorders.

The most intriguing finding was that serum nitrite concentrations were increased in patients with RA and OA compared with controls matched for age and sex. The origin of this nitrite is not clear; widespread synovial inflammation might increase serum nitrite when synovial fluid cleared by the lymphatic system enters the systemic circulation and by equilibration with the vascular compartment within the synovium. This may not entirely account for the higher serum nitrite concentration in RA compared with controls, however, and seems an unlikely explanation in patients with OA. A possible source of increased nitrite is the systemic vasculature and other cells in which the induction of nitric oxide has been shown. Although difficult to reconcile with current concepts of OA, this is compatible with the systemic nature of $R A$, in which circulating cytokines are evident ${ }^{23}$ and in which vasculitis is a common complication. The precise part played by nitric oxide in inflammation remains to be elucidated. Actions of nitric oxide relevant to this process include its role in the cytotoxic mechanism of activated macrophages, ${ }^{9}$ inhibition of iron-sulphur centred enzymes ${ }^{24}$ and its antiproliferative effects. ${ }^{25} 26$ Nitric oxide is also implicated in chemotaxis of polymorphonuclear leucocytes, ${ }^{27}$ and L-arginine, the precursor of nitric oxide, has been shown to have in vivo immunoregulatory actions. The latter include enhanced wound healing and $\mathrm{T}$ cell function, ${ }^{28}$ notably increased natural and lymphokine activated killer cell activity. ${ }^{29}$

The powerful vasodilating ${ }^{1}$ and platelet inhibitory ${ }^{6}$ actions of nitric oxide are also pertinent to rheumatoid synovitis. Microvascular injury is prominent in the latter and includes thrombus plugging and features typical of hypoxia. ${ }^{30}$ Evidence suggests that the latter is due to hypoxic reperfusion injury consequent on impaired synovial perfusion during joint exercise. ${ }^{19}$ In this situation nitric oxide induced vasodilatation and the removal of superoxide by reaction with nitric oxide might be protective. In vitro, however, the latter reaction yields hydroxyl radicals via the peroxynitrite anion. ${ }^{16} 17$ If the latter occurs to a considerable degree in vivo it may far outweigh the favourable actions of nitric oxide with the net effect of increasing microvascular and synovial tissue injury.

Further investigation is required to establish whether the overall effect of nitric oxide generated by the inducible enzyme is proinflammatory. There is clear evidence that induced nitric oxide synthesis leads to cellular injury, ${ }^{31}$ which is inhibited by glucocorticoids. ${ }^{8} 31$ The latter occurs at glucocorticoid concentrations within the therapeutic range and appears to be specific as the inhibitory effect is blocked in a concentration dependent manner by cortexolone, a partial agonist of glucocorticoid receptors. $^{8}$

We have shown highly significant differences between nitrite concentrations in synovial fluid and serum samples and in serum samples from patients with RA and OA compared with controls matched for age and sex. This suggests increased endogenous nitric oxide synthesis in these rheumatic diseases and nitric oxide production by the synovium and probably other tissues. It is likely that increased nitric oxide production may play a part in the pathogenesis of these and other diseases in which cytokines have been implicated. Nitrite provides a measure of endogenous nitric oxide synthesis and this study shows that nitrite may be measured in samples from humans without complex preparatory steps. These results should encourage other workers to use nitrite concentrations to examine alterations of nitric oxide biosynthesis in other diseases.

1 Palmer R M J, Ferrige A G, Moncada S. Nitric oxide accounts for the biological activity of endothelium-derived relaxing factor. Nature 1987; 327: 524-6.

2 Moncada S, Palmer R M J, Higgs A E. Nitric oxide: physiology, pathophysiology and pharmacology. Pharmacol Rev 1991; 43: 109-42.

3 Palacios M, Knowles R G, Palmer R M J, Moncada S. Nitric oxide from $L$-arginine stimulates the soluble guanylate cyclase in adrenal glands. Biochem Biophys Res Commun 1989; 165: 802-9.

4 Knowles R G, Palacios M, Palmer R M J, Moncada S. Formation of nitric oxide from $L$-arginine in the central nervous system: a transduction mechanism for stimulation of the soluble guanylate cyclase. Proc Natl Acad Sci USA 1989; 86: 5159-62.

5 Bredt S D, Snyder S H. Nitric oxide mediates glutamatelinked enhancement of cGMP levels in the cerebellum. Proc Natl Acad Sci USA 1989; 86: 9030-33.

6 Radomski M W, Palmer R M J, Moncada S. Comparative pharmacology of endothelium derived relaxing factor, pharmacology of endothelium derived relaxing factor, nitric oxide and

$7 \mathrm{Li} \mathrm{C} \mathrm{G}$, Rand M J. Evidence for a role of nitric oxide in the neurotransmitter system mediating relaxation of the rat anococcygeus muscle. Clin Exp Pharmacol Physiol 1989; 16: $933-8$.

8 Radomski M W, Palmer R M J, Moncada S. Glucocorticoids inhibit the expression of an inducible, but not the constitutive, nitric oxide synthase in vascular endothelial cells. Proc Natl Acad Sci USA 1990; 87: 10043-7.

9 Hibbs J B, Vavrin Z, Taintor R R. L-Arginine is required for the expression of the activated macrophage effector mechanism causing selective metabolic inhibition in target cells. F Immunol 1987; 138: 550-65.

10 McCall T B, Boughton-Smith N K, Paimer R M J, Whittle B J R, Moncada S. Synthesis of nitric oxide from L-arginine B J R, Moncada S. Synthesis of nitric oxide from

11 Kirk S J, Regan M C, Barbul A. Cloned murine T lymphocytes synthesize a molecule with the biological characteristics of nitric oxide. Biochem Biophys Res Commun 1990; 173: 660-5.

12 Curran R D, Billar T R, Steuhr D J, Hoffmann K, Simmons $R$ L. Hepatocytes produce nitrogen oxides from $L$-arginine in response to inflammatory products of Kupffer cells. $f$ Exp Med 1989; 170: 1769-74.

13 Kilbourn R G, Belloni P. Endothelial cell production of nitrogen oxides in response to interferon gamma in combination with tumour necrosis factor, interleukin-1 or endotoxin. 7 Natl Cancer Inst 1990; 82: 772-6.

14 Liew F Y, Li Y, Millott S. Tumor necrosis factor alpha synergizes with IFN gamma in mediating killing of Leishmania major through the induction of nitric oxide. Leishmania major through the

15 Gryglewski R J, Palmer R M J, Moncada S. Superoxide anion is involved in the breakdown of endothelium-derived is involved in the breakdown of end

16 Beckman J S, Beckman T W, Chen J, Marshall P A, Freeman B A. Apparent hydroxyl radical production by peroxynitrite: implications for endothelial injury from nitric oxide and superoxide. Proc Natl Acad Sci USA 1990; 87: 1620-4.

17 Yang G, Candy T E G, Boaro M, et al. Free radical yields from the homolysis of peroxynitrous acid. Free Radic Biol Med 1992; 12: 327-30.

18 Eastgate J E, Symons J A, Wood N C, Grinlinton F M, Di Giovine F S, Duff G W . Correlation of plasma interleukin 1 levels with disease activity in rheumatoid arthritis. Lancet 1988; 2: 706-9.

19 Blake D R, Merry P, Unsworth J, et al. Hypoxic-reperfusion injury in the inflamed joint. Lancet 1989; $i$ : 289-93.

20 Arnett F C, Edworthy F M, Bloch D A, et al. The American Rheumatism Association 1987 revised criteria for the Rheumatism Association 1987 revised criteria for the
classification of rheumatoid arthritis. Arthritis Rheum 1988; 31: 315-21.

21 Knight $T \dot{M}$, Forman D, Al-Dabbagh S A, Doll $R$. Estimation of dietary intake of nitrate and nitrite in Great Estimation of dietary intake of nitrate and nitrit

22 Green L C, Wagner D A, Glogowski J, Skipper P L, Wishnok J S, Tannenbaum S R. Analysis of nitrate, nitrite, and $\left({ }^{15} \mathrm{~N}\right)$ nitrate in biological fluids. Anal Biochem 1982; 126: $131-8$. 
23 Wagner D A, Schultz D S, Deen W M, Young V $R$ Tannenbaum S R. Metabolic fate of an oral dose of ${ }^{15} \mathrm{~N}$ labelled nitrate in humans: effect of diet supplementation with ascorbic acid. Cancer Res 1983; 43: 1921-5.

24 Stuehr D J, Nathan C F. Nitric oxide. A macrophage product responsible for cytostasis and respiratory inhibition in tumour target cells. $\mathcal{f}$ Exp Med 1989; 169: 1543-55.

25 Naxaki T, Nakayama $M$, Kato $R$. Inhibition by nitric oxide and nitric oxide producing vasodilators of DNA synthesis 189: $347-53$.

26 Albina J E, Mills C D, Henry W L, Caldwell M D. Temporal expression of different pathways of $\mathrm{L}$-arginin metabolism in healing wounds. f Immunol 1990; 144 3877-80.
27 Kaplan S S, Billar T R, Curran R D, Zdziarski U E, Simmons $R$ L, Basford R E. Inhibition of chemotaxis with $N$-monomethyl-L-arginine: a role for cGMP. Blood 1989; 74: $1885-7$.

28 Barbul A, Lazarou S A, Efron D T, Wasserkrug H L, Efron G. Arginine enhances wound healing and lymphocyte immune responses in humans. Surgery 1990; 108: 331-7.

29 Park K G M, Hayes P D, Garlick P J, Sewell H, Eremin O Stimulation of lymphocyte natural cytotoxicity by $L$ arginine. Lancet 1991; 337: 645-6.

30 Kulka J P. The pathogenesis of rheumatoid arthritis J Chronic Dis 1959; 10: 388-402.

31 O'Connor K J, Moncada S. Glucocorticoids inhibit the induction of nitric oxide synthase and the related cell damage in adenocarcinoma cells. Biochim Biophys Acta 1991; 1097: 227-31. 